\title{
Role for Runx1 in the Proliferation and Neuronal Differentiation of Selected Progenitor Cells in the Mammalian Nervous System
}

\author{
Francesca M. Theriault, ${ }^{1,2}$ Hugh N. Nuthall, ${ }^{1,2}$ Zhifeng Dong, ${ }^{1,2}$ Rita Lo, ${ }^{1,2}$ Fanie Barnabe-Heider, ${ }^{2,3}$ Freda D. Miller, \\ and Stefano Stifani ${ }^{1,2}$ \\ ${ }^{1}$ Center for Neuronal Survival, Montreal Neurological Institute, ${ }^{2}$ Department of Neurology and Neurosurgery, McGill University, Montreal, Quebec, H3A \\ 2B4 Canada, ${ }^{3}$ Developmental Biology, Hospital for Sick Children Research Institute, Toronto, Ontario, M5G 1X8 Canada, and ${ }^{4}$ Departments of Physiology \\ and Molecular and Medical Genetics, University of Toronto, Toronto, Ontario, M5S 1A8 Canada
}

Neurogenesis requires factors that regulate the decision of dividing progenitors to leave the cell cycle and activate the neuronal differentiation program. It is shown here that the murine runt-related gene Runxl is expressed in proliferating cells on the basal side of the olfactory epithelium. These include both Mash1 + olfactory receptor neuron (ORN) progenitors and NeuroD + ORN precursors. Disruption of Runxl function in vivo does not cause a change in Mash1 expression but leads to a decrease in the number of NeuroD + neuronal precursors and an increase in differentiated ORNs. These effects result in premature and ectopic ORN differentiation. It is shown further that exogenous Runxl expression in cultured olfactory neural progenitors causes an expansion of the mitotic cell population. In agreement with these findings, exogenous Runx1 expression also promotes cortical neural progenitor cell proliferation without inhibiting neuronal differentiation. These effects are phenocopied by a chimeric protein containing ETO, the eight twenty one transcriptional repressor, fused to the Runx1 DNA-binding domain, which suggests the involvement of transcription repression mechanisms. Consistent with this possibility, Runx1 represses transcription driven by the promoter of the cell cycle inhibitor $p 21^{C i p 1}$ in cortical progenitors. Together, these findings suggest a previously unrecognized role for Runx 1 in coordinating the proliferation and neuronal differentiation of selected populations of neural progenitors.

Key words: AML1; neural precursor; NeuroD; olfactory epithelium; Runx1; transcriptional repression

\section{Introduction}

One of the critical regulatory events during development is the coordination of cellular proliferation and differentiation. A number of different transcriptional regulators are known to function during both cell proliferation and differentiation and provide activities that are important for the balance between these states (Davis and Turner, 2001; Bertrand et al., 2002; Sherr, 2004).

A particular group of transcription factors important for the regulation of cell proliferation and differentiation are the members of the Runt/Runx family (Lund and van Lohuizen, 2002; Coffman, 2003). In both invertebrates and vertebrates, Runt/

\footnotetext{
Received Aug. 18, 2004; revised Jan. 12, 2005; accepted Jan. 13, 2005.

This work was supported by grants from the Neuromuscular Research Partnership/Canadian Institutes of Health Research (CIHR) (MOP-42479 and MGC-14971) and the Cancer Research Society Inc. to S.S. F.M.T. is the recipient of a Fonds de la Recherche en Santé du Québec (FRSQ) studentship, H.N.N. is a CIHR postdoctoral fellow, and S.S. is a senior scholar of the FRSQ. We thank Dr. N. Speck for the generous contribution of Runx $1^{\text {lacz/+ }}$ and Runx $1^{\text {rd/+ }}$ mouse lines; Drs. M. Osato, K. Shigesada, S. Nimer, and L. Freedman for the gift of plasmids; Drs. F. Guillemot and J. Drouin for the gift of antibodies; Dr. A. J. Roskams for advice on OE dissections; Dr. E. Hamel for providing access to a cryostat; Dr. T. Kennedy for helpful advice; and M. Bouchard-Levasseur and T. Basmacioglu for invaluable animal assistance.

Correspondence should be addressed to Stefano Stifani, Center for Neuronal Survival, Montreal Neurological Institute, Department of Neurology and Neurosurgery, McGill University, Montreal, Quebec, H3A 2B4 Canada. Email: stefano.stifani@mcgill.ca.

DOI:10.1523/JNEUROSCI.5108-04.2005

Copyright $\odot 2005$ Society for Neuroscience $\quad$ 0270-6474/05/252050-12\$15.00/0
}

Runx proteins act as DNA-binding factors that mediate either transcriptional activation or repression, depending on the promoter context. Consistent with their expression in various tissues and their involvement in the regulation of a number of different targets, Runt/Runx proteins participate in the control of several developmental mechanisms. For instance, the prototypical member of the family, Drosophila Runt, plays important roles during segmentation, sex determination, neurogenesis, and eye development. The mouse Runxl gene is required for definitive hematopoiesis, and its human homolog, termed acute myeloid leukemia (AML) 1, is targeted frequently by chromosomal translocations resulting in acute leukemias and a familial platelet disorder (Speck and Gilliland, 2002). The related mouse gene Runx2 is required for bone development, and the congenital bone disease cleidocranial dysplasia is caused by haploinsufficiency of the human RUNX2 gene (Lund and van Lohuizen, 2002; Coffman, 2003). The final member of the mammalian Runx family, Runx3, is important for the development of a specific population of spinal ganglion sensory neurons (Inoue et al., 2002; Levanon et al., 2002) and plays a role in controlling the proliferation of epithelial cells in the gastric mucosa (Lund and van Lohuizen, 2002).

Recent studies have demonstrated that mouse Runxl is expressed in restricted types of postmitotic motor and sensory neurons (Theriault et al., 2004). Disruption of Runxl function in vivo 
does not appear to perturb the initial generation of these cells but perturbs their postmitotic development, resulting in a loss of these neuronal subtypes (Theriault et al., 2004). These findings suggest that Runxl plays important roles in the postmitotic differentiation of selected neuronal cells in the central and peripheral nervous systems. In this study, we have investigated for the first time whether Runxl is also involved in mechanisms regulating the proliferation and differentiation of specific populations of neural progenitor cells. A combination of expression studies, loss-of-function studies, and gain-of-function studies strongly suggests that Runx1 participates in mechanisms that coordinate the proliferation and differentiation of olfactory receptor neuron (ORN) precursor cells. In agreement with this possibility, exogenous Runxl expression in cultured telencephalic (cortical) neural progenitor cells causes an increase in the number of proliferating cells but does not inhibit neuronal differentiation, resulting in the formation of supernumerary neurons. This activity requires the DNA-binding ability of Runx1 and involves transcription repression mechanisms. These findings identify new functions for Runx1 in the regulation of cell proliferation and differentiation in the mammalian nervous system.

\section{Materials and Methods}

DNA plasmids and adenovirus vectors. Plasmids pCMV2-FLAGRunx1(1-250) and pCMV2-FLAG-Runx1(1-378) were generated by PCR amplification of the corresponding regions of Runxl (information on oligonucleotide primers is available on request), followed by subcloning of the PCR products into pCMV2-FLAG digested with EcoRV. The religated plasmids were verified by sequencing. Construct pCMV2FLAG-Runx1, encoding the 453 residue-long AML1b protein corresponding to full-length Runx1 (Lutterbach and Hiebert, 2000) has been described (McLarren et al., 2000). Plasmids pEF-Bos-Runx1(R177Q) (from Drs. M. Osato and K. Shigesada, Institute for Virus Research, Kyoto University, Kyoto, Japan), pCMV5-Runx1/ETO (from Dr. S. Nimer, Memorial Sloan-Kettering Cancer Center, New York, NY), and pww-p21-Luc (containing a $\sim 7.9 \mathrm{~kb}$ region of the $p 21^{\text {Cip } 1}$ promoter; from Dr. L. Freedman, Memorial Sloan-Kettering Cancer Center, New York, NY) were obtained from the indicated investigators. Recombinant adenovirus vectors were generated as described by He et al. (1998) by first subcloning either FLAG-Runx1 or FLAG-Runx1(1-250) into the EcoRV site of the shuttle vector pAdTrack-CMV, which encodes the enhanced green fluorescent protein (GFP) under the control of a separate CMV promoter. The resulting constructs were linearized with $P m e I$ and transformed into Escherichia coli strain BJ5183 together with the adenoviral vector pAdEasy-1 to allow for homologous recombination in bacteria. Recombinants were selected for kanamycin resistance, and recombination was confirmed by restriction digestion analysis. The recombinant vectors were linearized with $\mathrm{PacI}$ and transfected into the human embryonic kidney 293 (HEK293) packaging cell line. The control GFPexpressing virus was obtained in the same way but by omitting the subcloning of any transgene. All adenovirus vectors were purified from the packaging cells by ultracentrifugation on $\mathrm{CsCl}$ gradients, as described (Toma et al., 2000).

Embryological analysis. Runx $1^{\text {lacZ/+ }}$ and Runx $1^{\mathrm{rd} /+}$ mice were generated and genotyped as described previously (Wang et al., 1996; North et al., 1999). The recombined locus of Runx $1^{\text {lacZ/+ }}$ mice encodes a fusion protein of the N-terminal 242 amino acids of Runx1 (containing a nuclear localization sequence) and $\beta$-galactosidase ( $\beta$-gal). The expression of this nuclear fusion protein in heterozygous animals was shown to faithfully reproduce the expression of RunxI transcripts (Simeone et al., 1995; North et al., 1999; Theriault et al., 2004). For staging of the embryos, the day of the appearance of the vaginal plug was considered as embryonic day 0.5 (E0.5). Embryos were dissected, fixed, cryostat sectioned, and processed for $\beta$-gal activity as described (Theriault et al., 2004). Double-labeling immunofluorescence experiments (Theriault et al., 2004) were performed using the following antibodies: rabbit anti- $\beta$ gal (1:5000; Cappel, West Chester, PA), rabbit anti-phospho-histone H3
(1:200; Upstate Cell Signaling Solutions, Charlottesville, VA), rabbit anti-NeuroD (1:750; kindly provided by Dr. J. Drouin, Institut de Recherches Cliniques de Montreal, Montreal, Quebec, Canada), mouse anti- $\beta$-gal (1:15; Developmental Studies Hybridoma Bank, Iowa City, IA; courtesy of Dr. J. Sanes, Washington University Medical School, St. Louis, MO), mouse anti- $\beta$ III-tubulin (1:25; Promega, Madison, WI), mouse anti-Ki67 (1:25; BD PharMingen, San Diego, CA), mouse antiMash1 (1:25; kindly provided by Dr. F. Guillemot, National Institute for Medical Research, Mill Hill, London, UK), and rat anti-NCAM (1:100; Chemicon, Temecula, CA).

Cell counting. Every third serial transverse section through the olfactory epithelium (OE) of Runx $1^{\text {lacZ/+ }}$ and Runx $1^{\text {lacZ/rd }}$ littermates was analyzed. The OE was operationally divided into two equal longitudinal halves, and the numbers of $\beta$-gal + cells were counted in $>25$ sections for each genotype ( $n=4$ embryos per genotype). The numbers of $\beta$-gal + / $\beta$ III-tubulin + cells ( $>20$ sections for each genotype; $n=3$ embryos per genotype) were counted in the same way. The Mash $1+/ \beta$-gal-, Mash $1+/ \beta$-gal + , NeuroD $+/ \beta$-gal + , and $\beta$-gal $+/$ phosphorylated histone $\mathrm{H} 3+$ cells were counted in the entire OE $(>20$ sections for each genotype; $n=3$ embryos per genotype).

Olfactory neural precursor cell cultures. The OE was carefully dissected from E18.5 CD-1 mouse embryos and dissociated by trituration with P1000 pipettor tips as described previously (Carter et al., 2004). Dissociated cells were resuspended $\left(2 \times 10^{5}\right.$ cells $\left./ \mathrm{ml}\right)$ in DMEM/F-12 (3:1) supplemented with $1 \% \mathrm{~N} 2,2 \% \mathrm{~B} 27,0.5 \mathrm{~mm}$ glutamine, $1 \%$ penicillinstreptomycin (Invitrogen,Gaithersburg, MD), 40 ng/ml FGF2, and 20 $\mathrm{ng} / \mathrm{ml}$ EGF (Collaborative Research), and cultured in T25 flasks as described (Othman et al., 2003; Zhang et al., 2004). After $\sim 4-6 \mathrm{~d}$ in vitro, floating "neurospheres" of $\sim 20-100$ cells became evident. The spheres were collected and either mechanically dispersed into individual cells and replated for generation of new spheres as described (Zhang et al., 2004) or used for immunocytochemistry assays. In the latter case, the neurosphere-forming cells were transferred to four-well chamber slides (Nalge Nunc, Naperville, IL) coated with $0.1 \%$ poly-D-lysine and $0.2 \%$ laminin (BD Biosciences, Franklin Lake, NJ), allowed to adhere for 3-4 d in the presence of DMEM/F-12 (3:1) supplemented with $1 \%$ FBS, $0.5 \mathrm{~mm}$ glutamine, and $1 \%$ penicillin-streptomycin, and then fixed and stained as described (Gratton et al., 2003; Nuthall et al., 2004). In agreement with previous studies (Othman et al., 2003; Zhang et al., 2004), OE neurospheres contained both proliferating cells expressing Ki67 and Mash1 and postmitotic cells exhibiting the morphological and immunological characteristics of neuronal and glial cells. Infections of floating neurosphere-forming cells with adenoviral vectors were started after $4 \mathrm{~d}$ in vitro and performed for $16-24 \mathrm{~h}$ at a multiplicity of infection (MOI) of 50. Cells were then transferred to coated four-well chamber slides, cultured, and allowed to adhere for 3-4 d as described above. After this time, cells were fixed and subjected to double-label immunocytochemical analysis of the expression of GFP and Ki67. Digital image acquisition and analysis were performed with Northern Eclipse software (Empix, Mississauga, Ontario, Canada). Results were expressed as mean values \pm SD.

Cortical neural progenitor cell cultures. Primary neural progenitor cell cultures were established from dorsal telencephalic cortices obtained from mouse embryos collected at E12.5-13.5 as described (Gratton et al., 2003). Cells were cultured in Neurobasal medium supplemented with $1 \% \mathrm{~N} 2,2 \%$ B27, $0.5 \mathrm{~mm}$ glutamine, $1 \%$ penicillin-streptomycin, and 40 $\mathrm{ng} / \mathrm{ml} \mathrm{FGF2}$. All chamber slides and dishes were coated with $0.1 \%$ polyD-lysine and $0.2 \%$ laminin. For transient transfection-transcription studies, $\sim 1.5 \times 10^{6}$ cells $/ \mathrm{ml}$ were seeded in six-well dishes at the start of the experiments. After $24 \mathrm{~h}$ in vitro, transfections were performed by mixing the appropriate plasmids (total amount of DNA was adjusted to $2.0 \mu \mathrm{g}$ per well in each transfection) with OptiMEM medium (Invitrogen). An equal volume of OptiMEM medium was mixed separately with Lipofectamine 2000 reagent (Invitrogen; $2.0 \mu \mathrm{l} / \mu \mathrm{g}$ of DNA) and then combined with the DNA mixture and incubated for $20 \mathrm{~min}$. The DNALipofectamine $2000 \mathrm{mix}$ was then added drop-wise to each well. In each case, a pRSV- $\beta$-gal plasmid was cotransfected to provide a means of normalizing the assays for transfection efficiency. Cells were harvested $24 \mathrm{~h}$ after transfection, and luciferase and $\beta$-gal activities were determined as described (McLarren et al., 2000; Yao et al. 2001). Results were 
expressed as mean values \pm SD. For immunocytochemical studies, $\sim 4 \times 10^{5}$ cells $/ \mathrm{ml}$ were seeded in four-well chamber slides at the start of the experiments. After $48 \mathrm{~h}$ in vitro, cells were transfected $(0.5 \mu \mathrm{g}$ per well $)$ with either plasmid pAdTrack-CMV (encoding GFP alone) or plasmid pAdTrack-CMV-Runx1 (encoding both GFP and Runx1). In a second strategy, cells either were transfected with a GFP expression plasmid (pEGFP) alone ( $0.2 \mu \mathrm{g}$ per well) or cotransfected with pEGFP and pCMV2-FLAGRunx1, pCMV5-Runx1/ETO, or pEF-BosRunxl(R177Q) $(0.5 \mu \mathrm{g}$ per well). The total amount of DNA was adjusted to $1.0 \mu \mathrm{g}$ per well. Infections with adenoviral vectors were performed at an MOI of 50. Cells were allowed to differentiate until day $4-5$ in vitro, when they were fixed and subjected to double-label immunocytochemical analysis of the expression of GFP, Ki67, nestin (1:50; mouse monoclonal from PharMingen), NeuroD, neuronal-specific nuclear protein (NeuN) (1:50; mouse monoclonal from Chemicon), or $\beta$ III-tubulin (1:2000; rabbit polyclonal from Research Diagnostics, Flanders, NJ). For bromodeoxyuridine (BrdU) incorporation studies, cells were pulsed with $4.0 \mu \mathrm{g} / \mathrm{ml}$ BrdU for $16 \mathrm{~h}$ and then subjected to immunocytochemistry with anti- $\beta$ III-tubulin and anti-BrdU (1:40; BD Biosciences) antibodies. Digital image acquisition and analysis were performed with Northern Eclipse software (Empix). Results were expressed as mean values $\pm \mathrm{SD}$.

Preparation of cell lysates and Western blotting analysis. HEK 293 cells were cultured and transfected as described (McLarren et al., 2000; Yao et al., 2001). Whole-cell lysates were prepared and subjected to Western blotting with either the rabbit polyclonal antibody "Ab1" against the N terminus of Runx1 (1:250; Oncogene Research Products) or anti-FLAG monoclonal antibody (1:10,000; Sigma, St. Louis, MO).

\section{Results}

Expression of Runxl in restricted populations of dividing cells in the olfactory pit

Runx 1 is expressed in selected subtypes of postmitotic motor and sensory neurons in the mouse embryonic nervous system (Theriault et al., 2004). To determine whether Runx1 might also be expressed in populations of mitotic neural progenitor cells, we examined the developing $\mathrm{OE}$ based on previous in situ hybridization studies demonstrating the presence of Runx1 transcripts in the nasal cavity of mouse embryos (Simeone et al., 1995). We determined Runxl expression using previously described (North et al., 1999) Runx $1^{\text {lacZ/+ }}$ mice in which expression of a $\beta$-gal gene introduced into the Runxl locus by homologous recombination faithfully reproduces the expression of Runx 1 transcripts (North et al., 1999; Theriault et al., 2004). Staining of transverse sections through E9.5 embryos did not reveal any $\beta$-gal expression in olfactory placodes (data not shown). Expression first became detectable at E10.5 in a small number of cells located in the frontal region of the olfactory pit, which at this stage contains a significant number of cells expressing the neuronal protein $\beta$ III-
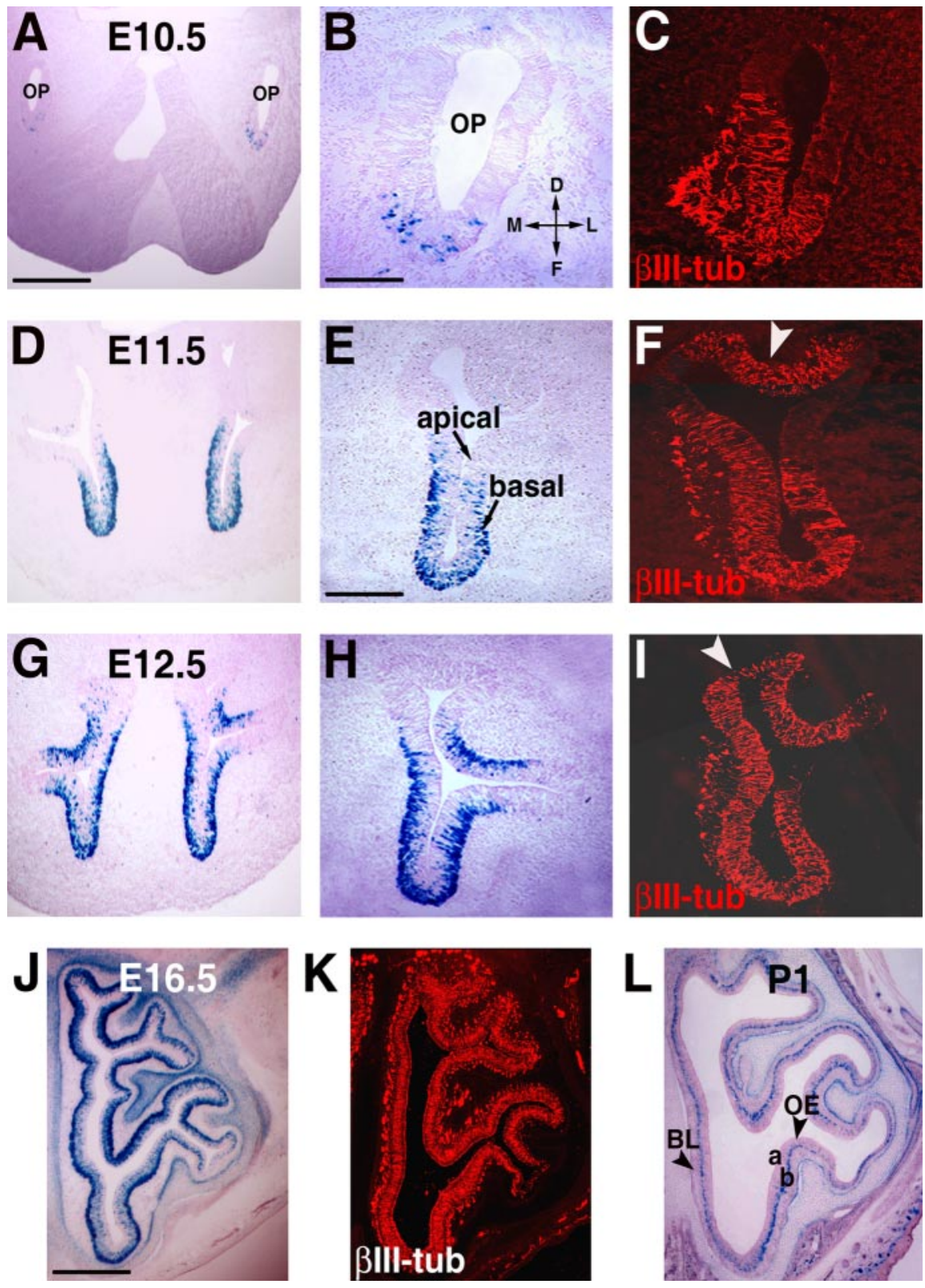

Figure 1. Analysis of Runx1 expression during olfactory neurogenesis. $\boldsymbol{A}-\boldsymbol{C}$, Expression of either $\beta$-gal $(\boldsymbol{A}, \boldsymbol{B}$; blue) or $\beta \mid \mathrm{II}-$ tubulin (C; red) in the olfactory pit of E10.5 Runx $1^{\text {lacZ/+ }}$ embryos. $\boldsymbol{D}$ - $\boldsymbol{L}$, Expression of $\beta$-gal $(\boldsymbol{D}, \boldsymbol{E}, \boldsymbol{G}, \boldsymbol{H}, \boldsymbol{J}, \boldsymbol{L})$ or $\beta$ III-tubulin $(\boldsymbol{F}, \boldsymbol{I}$, $\boldsymbol{K})$ in the 0 E ofE11.5 $(\boldsymbol{D}-\boldsymbol{F}), \mathrm{E} 12.5(\mathbf{G}-\boldsymbol{I}), \mathrm{E} 16.5(\boldsymbol{J}, \boldsymbol{K})$, or postnatal day $1(\boldsymbol{L})$ Runx $1^{\text {lacZ/+ }}$ embryos or pups. In all panels in which right. $\boldsymbol{E}$, The location of the apical and basal sides of the $0 \mathrm{E}$ is indicated. $\boldsymbol{F}, \mathbf{I}$, Arrowheads point to $\beta$ III-tubulin + cells located in regions where no $\beta$-gal expression is detected. a, Apical; b, basal; $B L$, basal lamina; $0 \mathrm{E}$, olfactory epithelium; OP, olfactory pit. Scale bars: $\boldsymbol{A}, \boldsymbol{D}, \mathbf{G}, 130 \mu \mathrm{m} ; \boldsymbol{B}, \boldsymbol{C}, 26 \mu \mathrm{m} ; \boldsymbol{J}, \boldsymbol{K}, \boldsymbol{L}, 95 \mu \mathrm{m}$.

tubulin, a marker of newly differentiating-differentiated neurons (Roskams et al., 1998) (Fig. $1 A-C$ ). These $\beta$ III-tubulin+ cells likely represent the first populations of ORNs that differentiate in the olfactory placode between E10.0 and E10.5 (Calof et al., 2002; Cau et al., 2002). No overlap between the expression of $\beta$-gal and $\beta$ III-tubulin was observed at this stage (data not shown). Instead, $\beta$-gal immunoreactivity marked cells that expressed the mitotic cell-marker protein Ki67 (Fig. 2A-C). These combined observations suggest that in the olfactory pit Runx1 expression is first activated in a subset of proliferating cells after the differentiation of the initial populations of ORNs derived from the olfactory placode. 


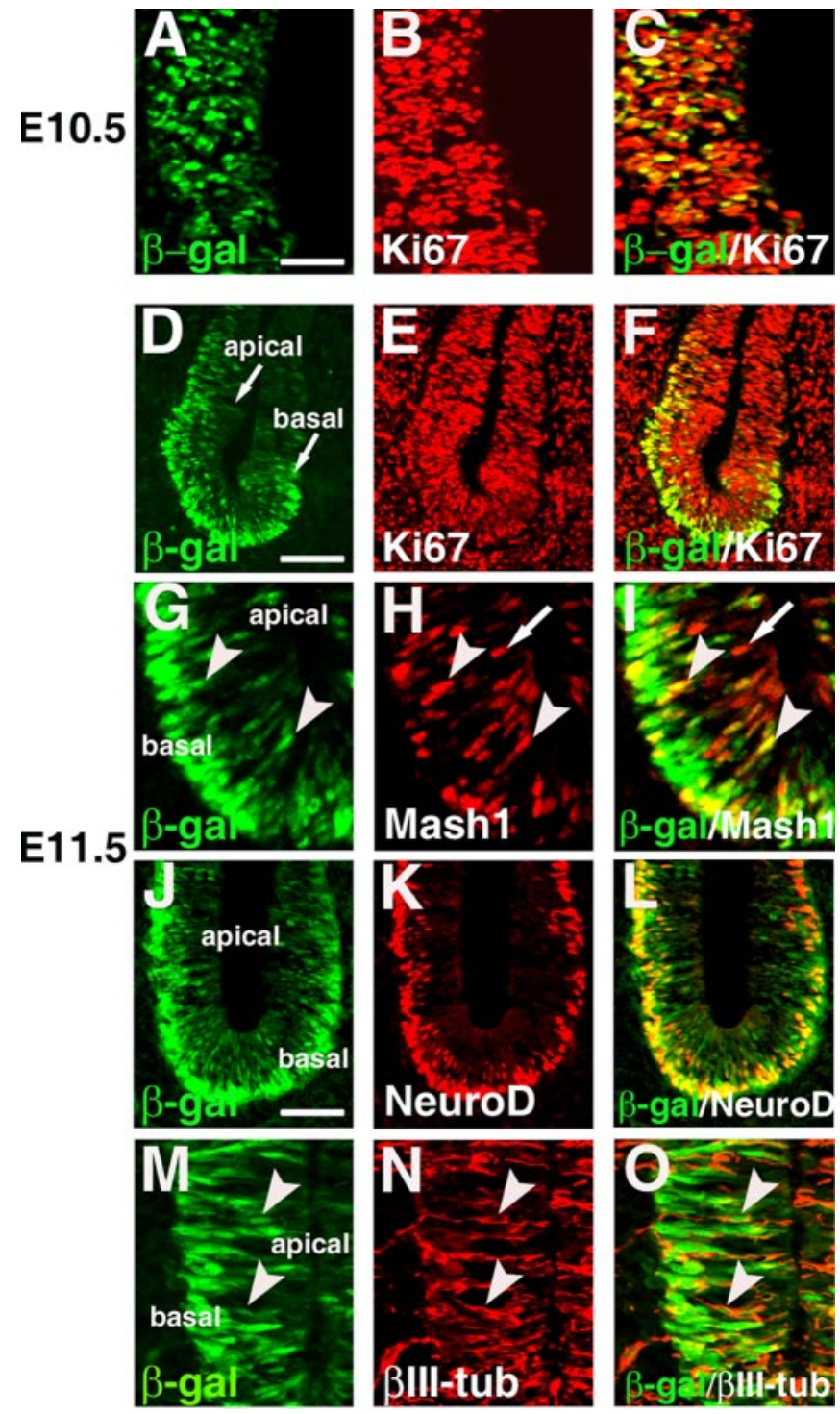

Figure 2. Expression of Runx 1 in dividing 0 RN progenitors and precursors on the basal side of the 0E. Either E10.5 (A-C) or E11.5 (D-0) Runx $1^{\text {lacz/+ }}$ embryos were subjected to immunocytochemical analysis of $\beta$-gal $(\boldsymbol{A}, \boldsymbol{D}, \boldsymbol{G}, \boldsymbol{J}, \boldsymbol{M}$; green), Ki67 ( $\boldsymbol{B}, \boldsymbol{E}$; red), Mash1 $(\boldsymbol{H} ;$; red), NeuroD ( $\boldsymbol{K}$ red), or $\beta$ III-tubulin ( $\boldsymbol{N}$; red). Combined expression of $\beta$-gal and Ki67 $(\boldsymbol{C}, \boldsymbol{F}), \beta$-gal and Mash1 $(\boldsymbol{I}), \beta$-gal and NeuroD ( $\boldsymbol{L})$, or $\beta$-gal and $\beta$ III-tubulin ( $\boldsymbol{O})$ is shown. The basal and apical sides of the $\mathrm{OE}$ are indicated in $\boldsymbol{D}, \mathbf{G}, \boldsymbol{J}$, and $\boldsymbol{M}$. $\mathbf{G}-\boldsymbol{I}$, Arrowheads point to examples of cells expressing both $\beta$-gal and Mash1; arrow points to an example of a cell expressing Mash1 but not $\beta$-gal. $\mathbf{M}-\mathbf{0}$, Arrowheads point to $\beta$-gal $+/ \beta$ III-tubulin + double-labeled cells. Scale bars: $\mathbf{A}-\mathbf{C}, \mathbf{G}-\mathbf{I}$, $\boldsymbol{M}-\mathbf{0}, 13 \mu \mathrm{m} ; \boldsymbol{D}-\boldsymbol{F}, 37 \mu \mathrm{m} ; \boldsymbol{J}-\boldsymbol{L}, 28 \mu \mathrm{m}$.

Expression of Runx1 in dividing basal ORN progenitors and precursors

We next examined Runx1 expression at later stages of development when the OE gradually acquires its layered organization composed of both undifferentiated progenitors and differentiating-differentiated ORNs. Two types of dividing cells are present on opposite sides of the OE. Those that proliferate on the apical side (Fig. $1 E$, see demarcation of the apical surface) are believed to derive from the neuroepithelial cells of the olfactory placode. During embryonic development, these apical cells act as "primary" progenitors that first undergo expansion and then, starting at $\sim$ E11.0, progressively lose their apical contacts and translocate to the basal side, where they continue to divide. The
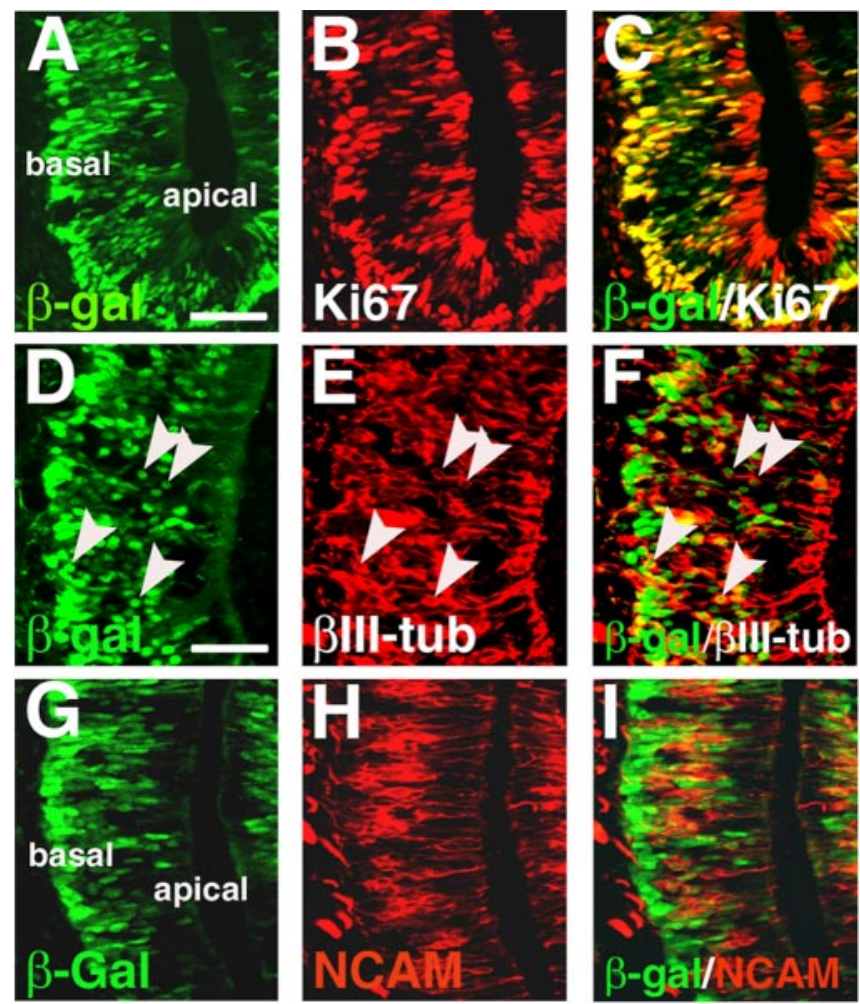

Figure 3. Expression of Runx 1 in the $0 \mathrm{E}$ at E14.5. Runx $1^{\text {lacz/+ }}$ embryos were subjected to immunocytochemical analysis of $\beta$-gal $(\boldsymbol{A}, \boldsymbol{D}, \mathbf{G}$; green), Ki67 ( $\boldsymbol{B} ;$ red), $\beta$ Ill-tubulin ( $\boldsymbol{E}$; red), or NCAM ( $\boldsymbol{H}$; red). Combined expression of $\beta$-gal and Ki67 (C), $\beta$-gal and $\beta$ III-tubulin $(\boldsymbol{F})$, or $\beta$-gal and NCAM $(\boldsymbol{I})$ is shown. The basal and apical sides of the 0 E are indicated in $\boldsymbol{A}$ and $\mathbf{G} . \boldsymbol{D}-\boldsymbol{F}$, Arrowheads point to double-labeled cells. Scale bars: $\mathbf{A}-\mathbf{C}, \mathbf{G}-\mathbf{I}, 28 \mu \mathrm{m} ; \mathbf{D}-\boldsymbol{F}, 13 \mu \mathrm{m}$.

relocation of apical progenitors to the basal surface is thought to coincide with their commitment to the ORN lineage and results in the appearance of determined "secondary" progenitors on the basal side (determination process). Basal progenitors undergo a limited number of cell divisions before they give rise to immediate neuronal precursors that first undergo proliferation on the basal side of the OE and then give rise to postmitotic ORNs (differentiation process). ORNs then move away from the basal side and come to reside in the intermediate region between the basal and apical compartments (Smart, 1971; Caggiano et al., 1994; Cau et al., 2002).

At E11.5, $\beta$-gal expression was readily detectable in the frontal half of the OE where it was predominantly localized to the basal side (Fig. $1 D, E$ ). A significant number of cells expressing $\beta I I I-$ tubulin were present in the same frontal domain of the OE (Fig. $1 F)$; however, we observed numerous $\beta$ III-tubulin + cells in more dorsal regions of the $\mathrm{OE}$, where $\beta$-gal expression was not detected (Fig. $1 F$, arrowhead). A similar expression pattern was observed between E12.5 and E14.5, except that $\beta$-gal expression gradually expanded to more dorsal regions of the OE (Fig. $1 G-I$ ) (and data not shown). At E16.5 (Fig. $1 J$ ) as well as postnatally (Fig. $1 L$ ), $\beta$-gal expression continued to be detected in basal cells throughout the OE.

The preferential expression of $\beta$-gal in basal OE cells suggests that Runx 1 is expressed in dividing ORN progenitors and/or precursors. In agreement with this possibility, we found that most of the basal $\beta$-gal + cells expressed Ki67 (Figs. $2 D-F, 3 A-C$ ), indicating that they correspond to proliferating cells. In contrast, little or no $\beta$-gal expression was observed in the separate Ki67+ population of primary progenitors located on the apical surface 
of the OE (Figs. $2 D-F, 3 A-C$ ). To directly determine whether the dividing $\beta$-gal + cells on the basal side of the $\mathrm{OE}$ corresponded to ORN progenitors, we next compared the expression of $\beta$-gal with that of Mash1, a protein that is expressed in certain, but not all, proliferating ORN progenitors but is not expressed in ORN precursors (Cau et al., 2002). In agreement with previous studies (Cau et al., 2002), we found that Mash1 was expressed in cells located in apical, intermediate, and basal positions at E11.5 (Fig. $2 \mathrm{H}$ ). A number of cells displayed overlapping $\beta$-gal and Mash1 expression on the basal side (Fig. $2 I$, arrowhead), whereas little overlap was observed in intermediate and apical compartments (Fig. 2I, arrow). These results suggest that Runxl is expressed in at least certain ORN progenitor cells that also express Mash1. The $\beta$-gal+/Mash1- cells may represent either separate populations of ORN progenitors that do not express Mash1 or differentiating ORN precursors that have switched off Mash1 expression (or both). To examine the latter possibility, we next tested whether $\beta$-gal expression overlapped with that of NeuroD, a protein that is activated downstream of Mash1 in proliferating basal ORN precursors and is important for neuronal differentiation (Cau et al., 1997). Virtually all NeuroD + cells in the basal compartment were also $\beta$-gal + (Fig. $2 J-L$ ), suggesting that Runxl is expressed in ORN precursors. Moreover, at both E11.5 (Fig. 2M-O, arrowhead) and E14.5 (Fig. 3D-F, arrowhead), we detected a small number of $\beta$-gal + cells that were positive for the early ORN marker $\beta$ III-tubulin. In contrast, $\beta$-gal expression did not overlap with that of NCAM, a protein expressed in more mature ORNs (Calof et al., 2002) (Fig. 3G-I). Together, these results show that Runxl is expressed in the ORN lineage. Moreover, they suggest that Runx1 expression is first activated in determined ORN progenitors and then persists in proliferating precursors undergoing differentiation; its expression becomes downregulated concomitant with or shortly after ORN differentiation.

\section{Reduced proliferation and premature differentiation of Runx1- expressing ORN precursors in Runx1-deficient embryos}

To determine the roles of Runxl during ORN differentiation, we examined embryos in which Runxl had been inactivated. Run $x 1^{\text {lacZ/+ }}$ mice were crossed to mice heterozygous for a disrupted Runxl allele lacking coding sequences for the DNAbinding Runt domain (Runxird/+ mice) (Wang et al., 1996). Doubly heterozygous Runx $1^{\text {lacZ/rd }}$ embryos lack Runxl activity and die at $\sim$ E12.5 because of impaired fetal liver-derived hematopoiesis (North et al., 1999). At E10.5, Runx1 $1^{\text {lacZ/rd }}$ embryos displayed neither quantitative nor qualitative changes in $\beta$-gal expression in the olfactory pit compared with heterozygous littermates (Fig. 4A,B). This suggests that Runxl inactivation does
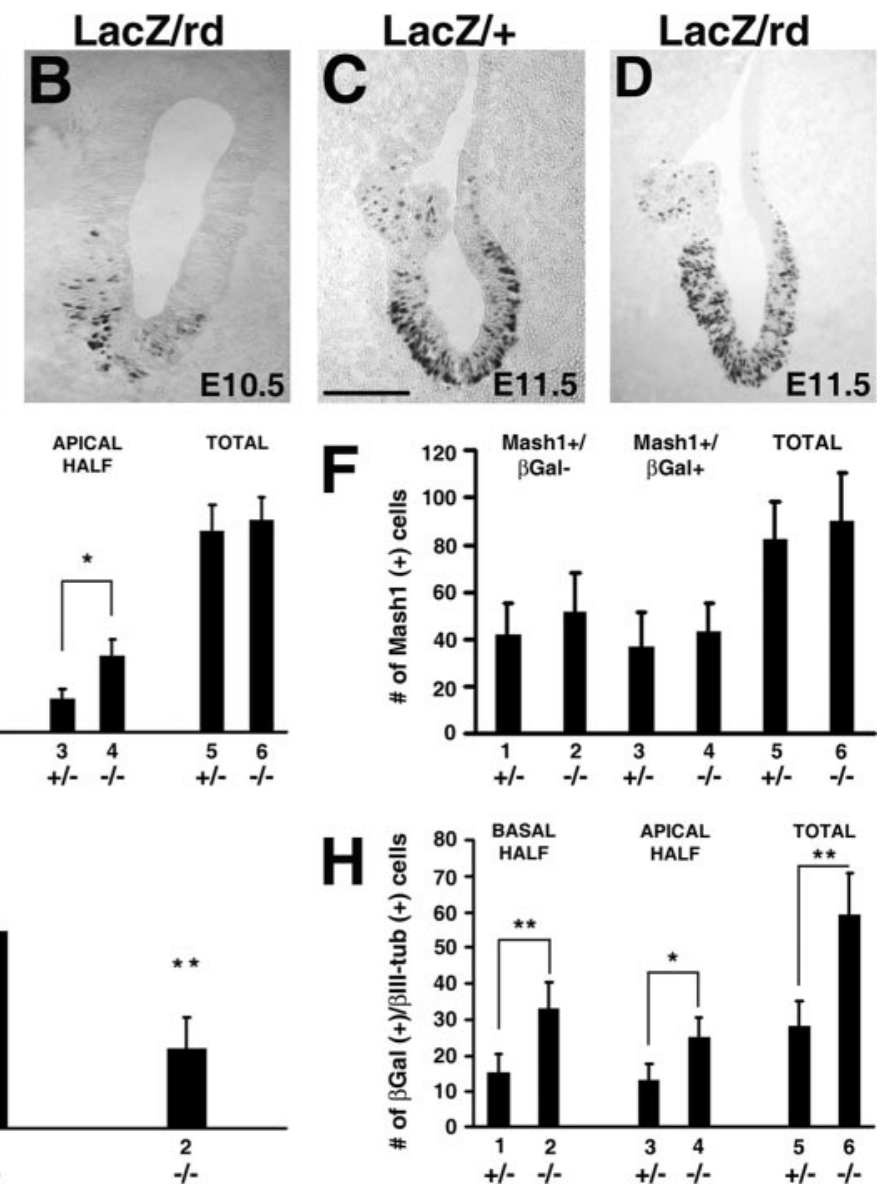

Figure 4. Effect of Runx1 inactivation on olfactory neurogenesis. $\boldsymbol{A}-\boldsymbol{D}$, Expression of $\beta$-gal (dark staining) in either the olfactory pit at $\mathrm{E} 10.5(\boldsymbol{A}, \boldsymbol{B})$ or the $0 \mathrm{E}$ at $\mathrm{E} 11.5(\boldsymbol{C}, \boldsymbol{D})$ of Runx $1^{\text {lacZ/+ }}(\boldsymbol{A}, \boldsymbol{C})$ or Runx $1^{\text {lacZ/rd }}(\boldsymbol{B}, \boldsymbol{D})$ embryos. $\boldsymbol{E}$, Analysis of the number of $\beta$-gal + cells in the basal half (bars 1,2 ), apical half (bars 3,4 ), or combined basal and apical halves (bars 5,6$)$ of the 0 E of 11.5 (bars 1, 2), Mash1+/ $\beta$-gal + cells (bars 3, 4), or combined counts (bars 5,6 ) in the $0 \mathrm{E}$ of E11.5 Runx $1^{\text {lacz } /+}$ (bars $1,3,5$ ) or (bars $2,4,6)$ embryos. G, Analysis of the total number of NeuroD $+/ \beta$-gal + cells in the $0 \mathrm{E}$ of E11.5 Runx $1^{\text {lacz/ } /+}$ (bar (bar 2) embryos; ${ }^{* *} p<0.001$. H, Analysis of the number of $\beta$-gal $+/ \beta$ III-tubulin + cells in the basal half (bars 1, 2), apical half (bars 3, 4), or combined basal and apical halves (bars 5, 6) of the OE of E11.5 Runx ${ }^{\text {lacz/+ }}$ (bars 1, 3, 5) or Runx $1^{\text {lacz/rd }}$ (bars $\left.2,4,6\right)$ embryos; ${ }^{*} p<0.01$; $^{* *} p<0.001 . A-D$, Dorsal is to the top, frontal is to the bottom, medial is to the left, and lateral is to the right. Scale bars: $A, B, 26 \mu \mathrm{m} ; \boldsymbol{C}, \boldsymbol{D}, 50 \mu \mathrm{m}$.

not cause reduced expression of $\beta$-gal and does not perturb the proliferation and/or survival of the olfactory cells in which it is expressed at this stage. To examine $\beta$-gal expression at E11.5, when the $\mathrm{OE}$ is already starting to exhibit a more layered organization, we operationally subdivided the OE into two longitudinal halves: (1) a "basal half" encompassing the basal progenitorprecursor compartment and part of the intermediate region containing differentiating-differentiated ORNs, and (2) an "apical half" containing the remaining part of the intermediate region and apical progenitor cells. Histochemical and cell-counting studies revealed that the total number of $\beta$-gal + cells in the combined basal and apical halves was similar in $R u n x 1^{\text {lacz/rd }}$ and Run $x 1^{\text {lacZ/+ }}$ littermates, suggesting that Runx 1 is not required for the survival of the OE cells in which it is expressed (Fig. 4C-E, bars 5, 6); however, Runx1-deficient embryos exhibited an increase in $\beta$-gal + cells in the apical half of the $\mathrm{OE}$ and a parallel decrease in the basal half (Fig. 4E, bars 1-4). This situation suggests that the basal ORN precursors that would have expressed Runxl had this gene not been inactivated might undergo premature neuronal differentiation resulting in an anticipated migration away from the basal compartment. 
To test this possibility, we first examined the expression of Mash1 in Runx1-deficient and control embryos. Comparison of the numbers of Mash $1+/ \beta$-gal- and Mash $1+/ \beta$-gal + cells revealed no difference between Runx $1^{\text {lacZ/rd }}$ and Runx $1^{\text {lacZ/+ }}$ littermates (Fig. 4F). These findings suggest that Runxl activity is not important for the generation or proliferation of Mash1+ ORN progenitors. Moreover, they suggest that Runxl inactivation does not cause a general perturbation of cell proliferation and/or survival in the OE. In contrast, Runx1-deficient embryos displayed a significant reduction in the number of NeuroD $+/ \beta$-gal + cells compared with control embryos (Fig. $4 G$ ). This reduction, combined with the fact that both the total number of $\beta$-gal + cells and that of Mash $1+/ \beta$-gal + cells were unaltered, suggests that Runx1 is not important for the survival of ORN progenitors or their transition to precursors. Instead, they suggest a role for Runxl in the transition from proliferating precursors to neurons. To examine this possibility, we compared the numbers of $\beta$-gal $+/ \beta$ III-tubulin + cells in the OE of Runx $1^{\text {lacZ/rd }}$ and Runx $1^{\text {lacZ/+ }}$ embryos. These studies revealed an increase in $\beta$-gal $+/ \beta$ III-tubulin + cells in both the basal and apical halves of the OE of Runx1-deficient embryos (Fig. 4H). These combined results suggest that Runxl is important for the proliferation of ORN precursors and that in its absence these cells leave the cell cycle and differentiate prematurely, resulting in a downregulation of NeuroD expression.

To test these possibilities further, we next examined the expression of $\beta$ III-tubulin and NCAM in the OE of E11.5 Run $x 1^{\text {lacZ/+ }}$ and Runx $x 1^{\text {lacZ/rd }}$ littermates. In $R u n x 1^{\text {lacZ/+ }} \mathrm{em}-$ bryos, differentiated ORNs occupied most of the frontomedial portion of the OE, whereas only the frontal half of the lateral region contained ORNs. This pattern resulted in a characteristic dorsolateral boundary of $\beta$ III-tubulin or NCAM expression (Fig. $5 A, E$, horizontal line). In Runx1-deficient embryos, this boundary appeared to have moved to more dorsal positions because considerable numbers of differentiated ORNs were detected prematurely in the dorsolateral OE (Fig. $5 B, F$, arrowheads). This phenotype was observed at different rostrocaudal levels of the $\mathrm{OE}$ (Fig. 5A-D) (and data not shown). Parallel studies with antibodies against phosphorylated histone $\mathrm{H} 3$, a marker of cells undergoing M phase (Galli et al., 2004), showed a decrease in the number of $\beta$-gal $+/$ phosphorylated histone $\mathrm{H} 3+$ cells in the OE of Runx1-deficient embryos (data not shown). Together, these findings implicate Runxl in the mechanisms that coordinate the transition from proliferating precursors to postmitotic ORNs. In particular, they suggest that Runxl is important for the sustained proliferation of ORN precursors and that these cells differentiate prematurely when Runxl is inactivated.

\section{Increased numbers of dividing cells after exogenous Runx1 expression in primary cultures of $\mathrm{OE}$-derived neurosphere-forming cells}

To further test the possibility that Runx1 is important for the proliferation of ORN precursor cells, we next performed gain-offunction studies. The OE was dissected from E18.5 embryos, and primary cultures of floating neurosphere-forming cells (Fig. 6A) were established as described previously (Othman et al., 2003; Zhang et al., 2004). After they were plated on an adhesive substratum, these OE-derived neurospheres were shown to contain proliferating cells expressing Mash1 (Fig. 6B) and Ki67 (Fig. 6F), as well as cells exhibiting morphological and immunological characteristics of neuronal cells such as the expression of $\beta$ III-tubulin (Fig. 6D) (Othman et al., 2003; Zhang et al., 2004). Moreover, neurospheres obtained from the OE of pooled Runx $1^{\text {lacz/+ }}$ and Runx $1^{+/+}$embryos contained numerous cells that coexpressed $\beta$-gal and Ki67 (Fig. 6F-H). This

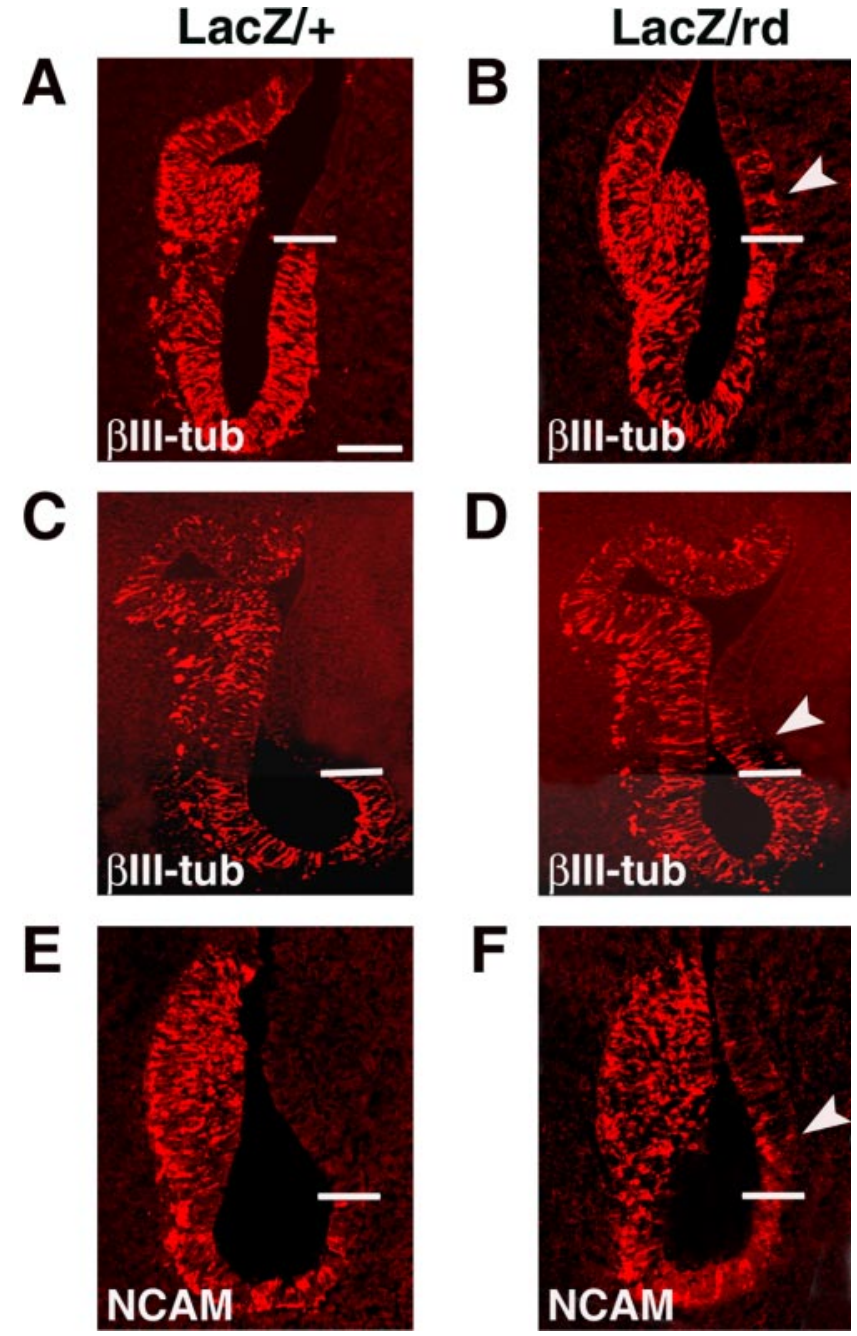

Figure 5. Effect of Runx1 inactivation on ORN differentiation. $\boldsymbol{A}-\boldsymbol{F}$, Expression of $\beta$ IIItubulin $(\boldsymbol{A}-\boldsymbol{D})$ or NCAM $(\boldsymbol{E}, \boldsymbol{F})$ in the 0 E of either Runx $1^{\text {lacZ/+ }}(\boldsymbol{A}, \boldsymbol{C}, \boldsymbol{E})$ or Runx $1^{\text {lacz/rd }}(\boldsymbol{B}, \boldsymbol{D}, \boldsymbol{F})$ embryos at E11.5. The arrowheads point to the ectopic neuronal cells present in the dorsolateral

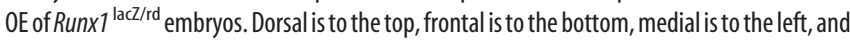
lateral is to the right. Scale bars, $35 \mu \mathrm{m}$.

observation is in agreement with the in vivo expression of $\beta$-gal in ORN progenitor-precursors and further confirms the OE origin of the cultured cells.

To assess the role of Runxl in the proliferation of OE-derived neurosphere-forming cells, we performed infections with adenovirus vectors driving expression of either enhanced GFP alone or a combination of Runx1 and GFP. After plating on an adhesive substratum, the numbers of proliferating GFP + cells that expressed Ki67 were counted 3-4 d after infection. Previous studies have shown that ORN progenitor cells have a limited proliferative capacity when cultured in vitro, with most of the cells rapidly giving rise to neurons that die shortly thereafter (Mumm et al., 1996; Calof et al., 2002). In agreement with those observations, we found that only $11 \pm 2 \%$ of the cells infected with GFP alone expressed Ki67 (Fig. 6I). Importantly, the exogenous expression of Runx 1 was correlated with a significant increase in the number of Ki67+ cells compared with control conditions (Fig. 6I). This expansion of the dividing cell population caused by exogenous Runx1 is in agreement with the converse observation that there are decreased numbers of proliferating ORN precursor cells in the OE of Runx1-deficient embryos. Together, these findings 

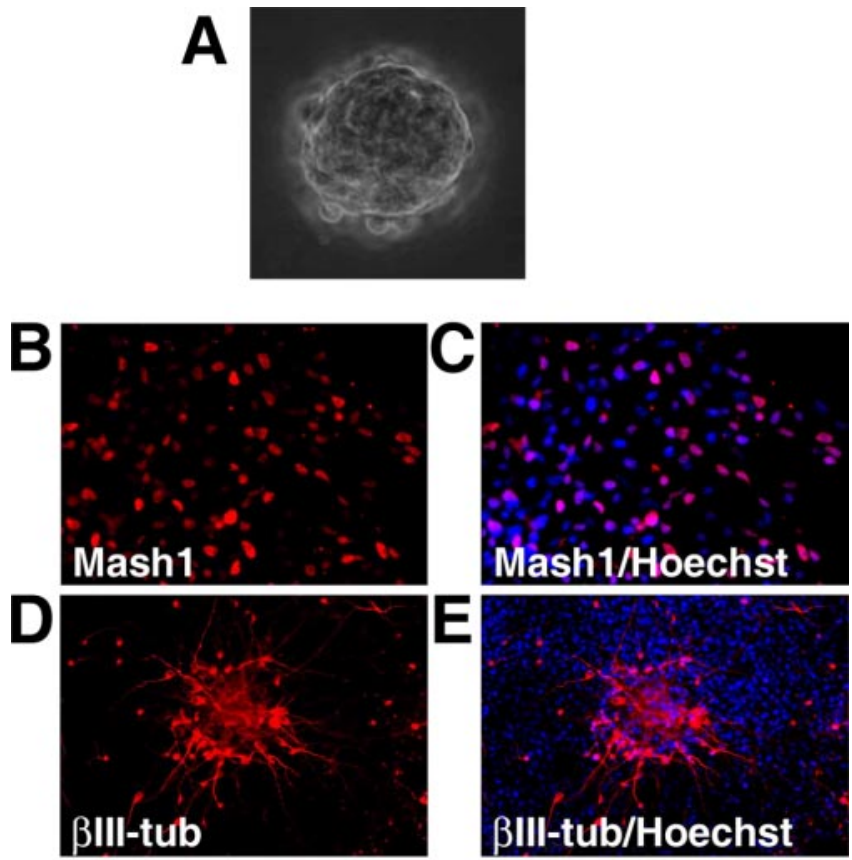
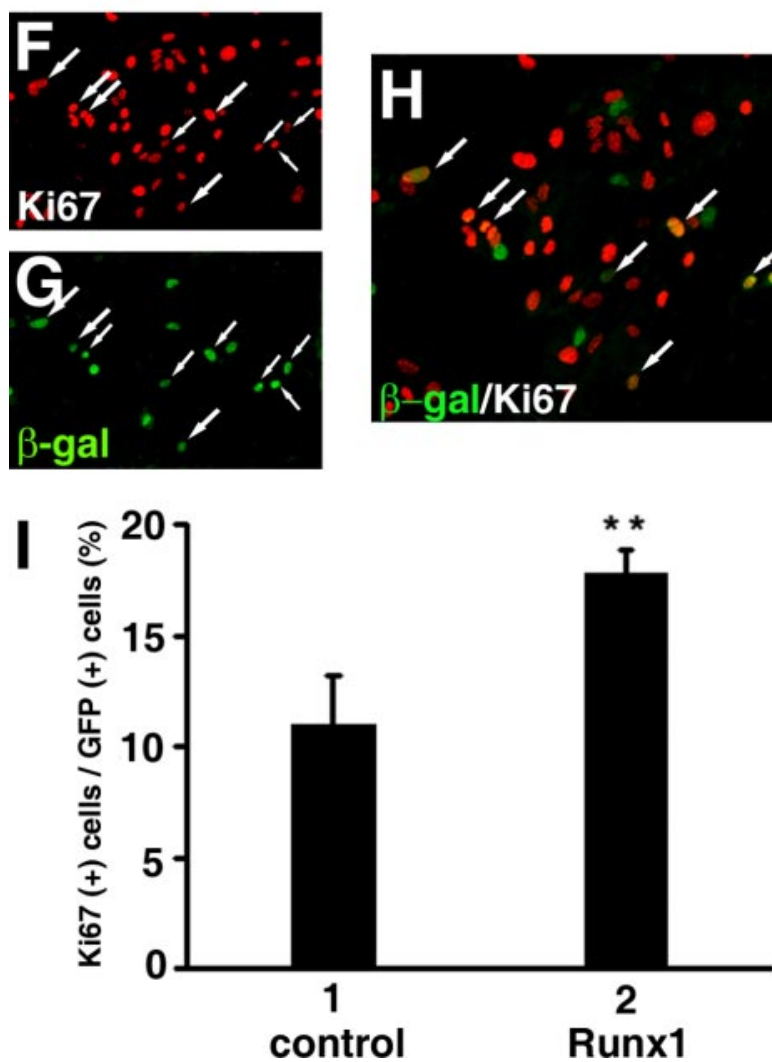

Figure 6. Exogenous expression of Runx 1 in $0 \mathrm{E}-$ derived neurospheres. $\boldsymbol{A}$, Phase-contrast microscopy of a representative 0 E neurosphere after $6 \mathrm{~d}$ in vitro. $\boldsymbol{B}-\boldsymbol{E}$, Expression of Mash1 (B) and $\beta I I I-t u b u l i n(D)$ in cells of neurospheres derived from the 0 E of E18.5 mouse embryos. $\boldsymbol{C}$, Combined Mash 1 and Hoechst staining. $\boldsymbol{E}$, Combined $\beta$ III-tubulin and Hoechst staining. $\boldsymbol{F}-\boldsymbol{H}$, Expression of Ki67 $(\boldsymbol{B})$ or $\beta$-gal $(\boldsymbol{C})$ in neurospheres derived from the $\mathrm{OE}$ of pooled $\mathrm{E} 18.5$ Runx $1^{+/+}$and Runx $7^{\text {lacz/+ }}$ embryos. $\boldsymbol{H}$, Combined expression of $\beta$-gal and Ki67; arrows point to double-labeled cells. Because of the presence of cells derived from wild-type embryos, not all Ki67+ cells are $\beta$-gal $+. I, 0$ E neurospheres were infected with recombinant adenovirus expressing GFP alone (control, bar 1) or in combination with Runx1 (bar 2). Cells then were subjected to double-labeling analysis of the expression of GFP and Ki67. Results from six separate infection experiments were quantified as percentage of GFP + cells that were positive for Ki67 (mean \pm SD; $>2000$ cells; ${ }^{* *} p<0.001$ ). strongly suggest that Runx1 is important for promoting the proliferation of ORN precursor cells.

Increased proliferation and neuronal differentiation after exogenous Runx1 expression in cortical neural progenitor cells The limited proliferative capacity of cultured ORN precursor cells and the poor viability of their neuronal progeny made it difficult to perform more detailed gain-of-function studies aimed at elucidating the mechanisms underlying Runx1 function in neural progenitor-precursor cells. Therefore, additional studies were performed using primary cultures of proliferating, pluripotent neural progenitor cells obtained from the dorsal telencephalon of E13.5 mouse embryos (cortical progenitor cells). This defined primary culture system has been used to examine the functions of a number of extrinsic and intrinsic factors during proliferation and neuronal differentiation (Ghosh and Greenberg, 1995; Toma et al., 2000; Gratton et al., 2003; Nuthall et al., 2004). We found that Runxl was endogenously expressed in cultured cortical progenitor cells (Fig. 7A, lane 3). More importantly, transient transfection of exogenous Runx1 led to a significant increase in the number of proliferating cells expressing Ki67 compared with GFP alone (Fig. $7 B, C$, bars 1,2). In agreement with this finding, we also observed an increase in the number of cells expressing the neural progenitor cell-marker nestin when Runx1 was exogenously expressed using an adenovirus vector (Fig. 7D, bars 1,2). In contrast, Runx1(1-250), a truncated form lacking the C-terminal 203 amino acids containing transcription activation and repression domains important for Runx1 activity (Kanno et al., 1998), did not promote an expansion of the nestin + cell population, indicating that the effect caused by Runx 1 was specific and required a transcriptionally competent form of this protein (Fig. 7D, bars 1, 3). Runx1 and Runx1(1-250) were expressed at equivalent levels (Fig. $7 G$ ). These results strongly suggest that exogenous Runxl expression leads to increased numbers of neuronal progenitor-precursor cells. In agreement with this possibility, Runx1 expression was correlated with a significant increase in the number of NeuroD + cells compared with GFP alone (Fig. 7F).

We next tested whether Runxl promoted an expansion of the proliferating progenitor cell population at the expense of neuronal differentiation. The transfected cells were subjected to immunocytochemistry with antibodies against the neuron-specific proteins NeuN and $\beta$ III-tubulin. We found that the increase in the number of dividing progenitors caused by exogenous Runx1 was not correlated with a decrease but rather an increase in the number of differentiated neurons compared with GFP alone (Fig. $7 C$, bars 3, 4, E, bars 1, 2). In contrast, Runx1(1-250) did not have a similar effect (Fig. 7E, bars 2, 3). In these assays, cells that expressed NeuN or $\beta I I I-t u b u l i n$ also exhibited a neuronal morphology with numerous processes (data not shown). Together, these results suggest that Runx1 increases the number of undifferentiated cortical neural progenitor-precursors without blocking their ability to undergo neuronal differentiation, resulting in the generation of supernumerary neurons from an expanded pool of progenitors.

The combined number of both GFP $+/ \mathrm{Ki} 67+$ and GFP+/ $\mathrm{NeuN}+$ cells was $>100 \%$ when Runxl was exogenously expressed (Fig. 7C). A similar observation was made when neural progenitors or neurons were identified through the expression of nestin (Fig. 7D) or $\beta$ III-tubulin (Fig. 7E), respectively. This situation suggests that exogenous expression of Runx1 may cause a perturbation of the mechanisms that coordinate the transition of progenitor cells into neurons. To examine this possibility, we 

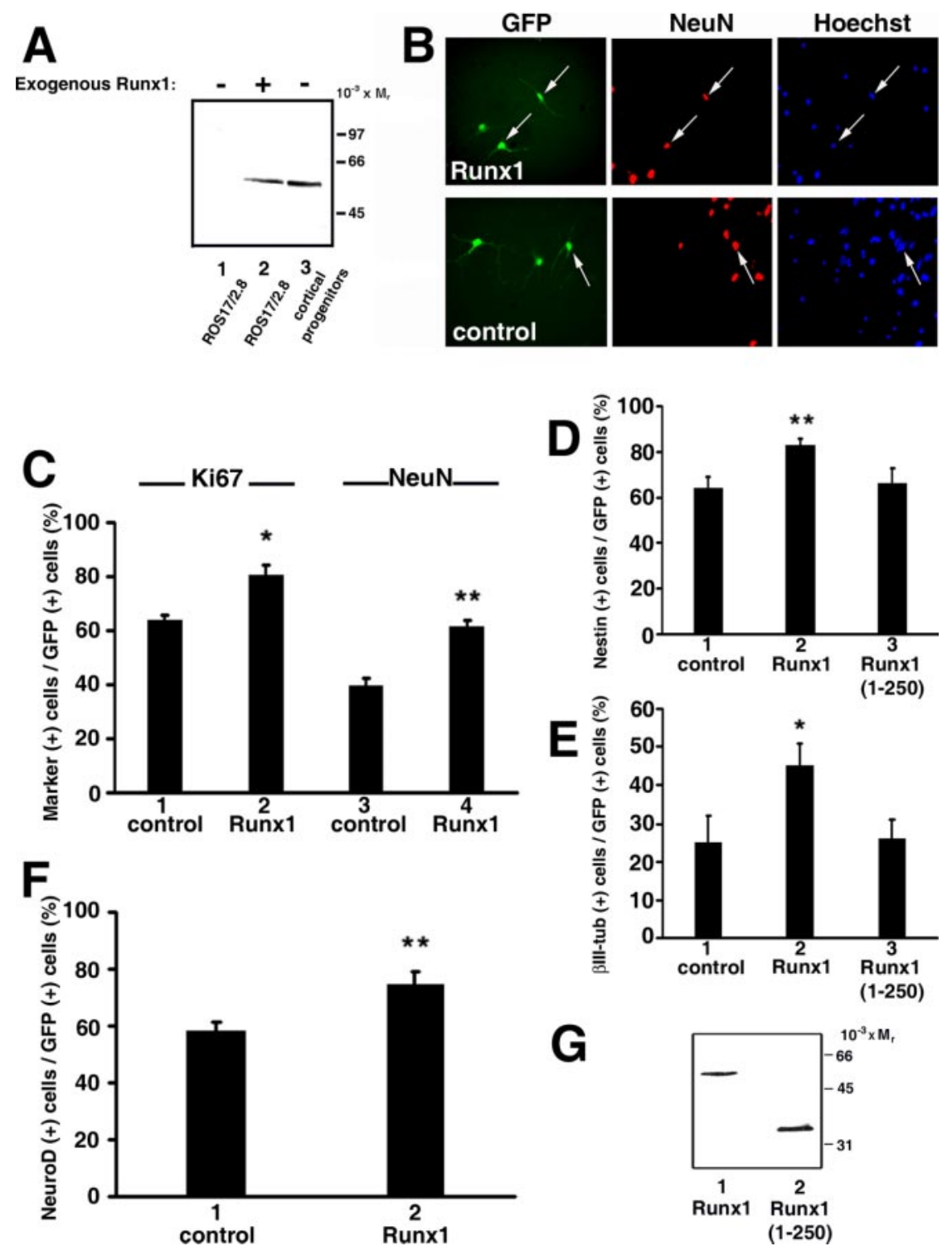

Figure 7. Exogenous expression of Runx 7 in cortical neural progenitor cells. $A$, Western blotting analysis either of ROS17/2.8 rat osteoblastic cells not transfected (lane 1) or transfected (lane 2) with Runx1 or of untransfected cortical progenitor cells (lane 3) using anti-Runx 1 antibodies. B, Cortical progenitor cells were transfected with GFP alone (control) or in combination with Runx1, followed by double-labeling analysis of the expression of GFP (left panels), the neuronal marker NeuN (middle panels), or Ki67 (data not shown). Hoechst staining is shown in the right panels. Arrows point to double-labeled cells. C, Results from transfection experiments were quantified as percentage of GFP + cells that were positive for either Ki67 (bars 1, 2) or NeuN (bars 3, 4) (mean $\pm S D ;>2000$ cells; $n=4 ;{ }^{*} p<0.01 ;{ }^{* *} p<0.001$ ). D, E, Cortical progenitor cells were infected with recombinant adenovirus expressing GFP alone (control, bar 1) or in combination with either Runx1 (bar 2) or a truncated form of Runx1 (Runx1(1-250), bar 3). Cells were then subjected to double-labeling analysis of the expression of GFP, the neural progenitor marker nestin $(\boldsymbol{D})$, or the neuronal marker $\beta$ III-tubulin $(\boldsymbol{E})$, and results were quantified as described above (mean $\pm S D ;>20,000$ cells; $n=5 ;{ }^{*} p<0.01 ;{ }^{* *} p<0.001$ ). $\boldsymbol{F}$, Cortical progenitor cells were transfected with GFP alone (control) or in combination with Runx1, followed by double-labeling analysis of the expression of GFP and NeuroD and quantitation as described above $(n=3$; $\left.{ }^{* *} p<0.001\right)$. G, Western blotting analysis of the expression of the indicated FLAG-tagged proteins using anti-FLAG antibodies.

tested whether Runx1 caused an increase in the number of cells that expressed both Ki67 and $\beta$ III-tubulin compared with GFP alone. A small number of Ki67+/ $\beta$ III-tubulin + cells were normally observed under control conditions. This number was increased $\sim 2.5$-fold in the presence of Runx1 (Fig. $8 A, B$ ). Similar results were observed both 3 and $5 \mathrm{~d}$ after transfection; moreover, terminal deoxynucleotidyl transferase-mediated biotinylated UTP nick end labeling investigations did not suggest that the $\mathrm{Ki67}+/ \beta \mathrm{III}-$ tubulin + cells were undergoing cell death at a higher rate than Ki67+ cells (data not shown). In agreement with these findings, studies measuring BrdU incorporation into proliferating cells showed that exogenous Runxl caused an increase in the number of cells immunoreactive for both BrdU and $\beta$ III-tubulin (Fig. $8 C$ ). Together, these findings suggest that Runx1 promotes neural progenitor cell proliferation and participates in mechanisms that coordinate cell cycle progression with the activation of the neuronal differentiation program.

Transcription repression mechanisms are involved in Runxl functions in cortical neural progenitor cells

Runx proteins are DNA-binding factors that can mediate either transcriptional activation or repression depending on the promoter context (Lutterbach and Hiebert, 2000). To determine whether the activity of Runx1 in cortical progenitor cells required DNA binding, these cells were transfected with Runx1(R177Q) (Osato et al., 1999), a point-mutated form of Runx1 with impaired DNA-binding activity. In contrast to Runx1, exogenous expression of Runx1(R177Q) did not promote an expansion of the progenitor cell population (Fig. 9A, bars 1,2, 4), although Runx1(R177Q) was properly expressed (Fig. 9C). Instead, we found that Runx1(R177Q) caused a statistically significant reduction in the number of Ki67+ cells when compared with GFP alone (Fig. $9 A$, bars 1,4). These observations show that the DNA-binding ability of Runx1 is required to promote progenitor cell proliferation and suggest that Runx1(R177Q) may interfere in a dominant inhibitory manner with mechanisms involving endogenous Runx1, possibly by sequestering important cofactors away from DNA. Interestingly, the decrease in dividing progenitors associated with the expression of Runx1(R177Q) was not correlated with a decreased number of differentiated neurons compared with GFP (Fig. 9B, bars 1, 4). These results suggest that a dominant inactivation of Runxl activity may cause a premature exit from the cell cycle and activation of the neuronal differentiation program in cortical progenitor cells.

We next examined whether the DNAbinding-dependent function of Runx1 involved transcription repression mechanisms. Neural progenitor cells were transfected with the chimeric protein AML1/ETO (for consistency, we will refer to AML1/ETO as Runx1/ETO), the naturally occurring protein product of the $\mathrm{t}(8 ; 21)$ chromosomal translocation found in $\sim 12 \%$ of human acute myeloid leukemias (Lutterbach and Hiebert, 2000; Speck and Gilliland, 2002). This translocation fuses the DNA-binding domain of Runxl to the eight twenty one (ETO) transcription repression protein. Runx1/ETO is considered to act as a transcriptional repressor that can bind to the 


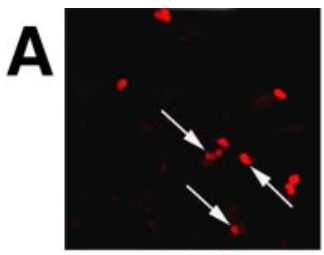

Ki67

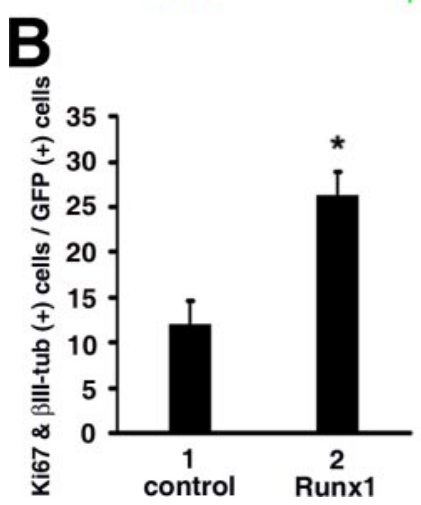

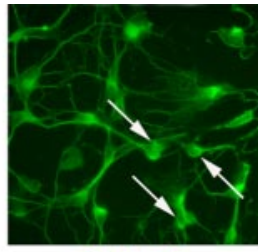

BIII-tub

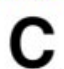

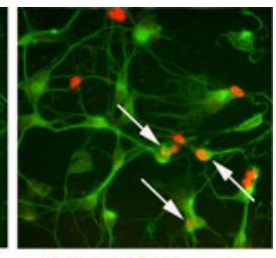

Ki67//III-tub
Figure 8. A, Double-labeling analysis of cortical progenitor cells with Ki67 (left panel; green) and $\beta$ III-tubulin (middle panel; red) antibodies. Combined staining is shown in the right-hand panel; arrows point to double-labeled cells. B, Quantification of the numbers of Ki67+/ $\beta$ IIItubulin +/GFP + cells in cortical progenitor cultures transfected with GFP alone (bar 1) or a combination of GFP and Runx1 (bar 2). C, Quantification of the numbers of BrdU + / $\beta$ III-tubulin +/GFP + cortical progenitor cells transfected with GFP alone (bar 1 ) or a combination of GFP and Runx1 (bar 2) and then incubated in the presence of $\operatorname{BrdU}\left(n=4 ;{ }^{* *} p<0.001\right)$.

promoters of Runx1 target genes and suppress their expression (Lutterbach and Hiebert, 2000; Linggi et al., 2002). Exogenous expression of Runx1/ETO resulted in effects that were essentially identical to those elicited by Runx1, namely the presence of supernumerary dividing progenitors (Fig. 9A, bars 1-3) and differentiated neurons (Fig. 9B, bars 1-3). These findings strongly suggest that the functions of Runxl in cortical progenitor cells involve transcription repression mechanisms.

To directly test whether Runx1 was able to mediate transcriptional repression in neural progenitor cells, we examined its effect on the promoter of the cell cycle inhibitory gene $p 21^{C i p 1}$, which was shown to be repressed by Runx1 in nonneural cells (Lutterbach et al., 1999). A reporter plasmid containing the luciferase gene under the control of the $p 21^{\text {Cip } 1}$ promoter was transfected in cortical progenitor cells in the absence or presence of Runx1. Transcription from this promoter was repressed by Runx1 (Fig. 9D, bars 1,2) at a level comparable with that observed in non-neural cells (Lutterbach et al., 1999). Runx1(1-378), a mutated form lacking the C-terminal region involved in recruiting the Groucho (Gro)/ transducin-like Enhancer of split (TLE) corepressor (McLarren et al., 2000), repressed $p 21^{\text {Cipl } 1}$ promoter activity like fulllength Runx1 (Fig. 9D, bars 1-3), suggesting that this repression activity is independent of Gro/TLE. In contrast, the DNA-binding defective protein Runx1(R177Q) did not repress this promoter (Fig. 9D, bar 4). The observed effects were specific because neither Runx1 nor Runx1(1-378) suppressed a control promoter (Fig. 9D, bars 5-8). Together, these results show that Runxl can act as a transcriptional repressor in cortical progenitor cells and suggest that its repressive activity is involved in mechanisms that coordinate the progenitor-toneuron transition.

\section{Discussion}

Runx 1 is expressed in restricted regions of the murine embryonic nervous system, and recent studies have demonstrated its involvement in the postmitotic development of certain populations of central and peripheral neurons (Theriault et al., 2004); however, a role for Runx1 in neural progenitor cells had not been investigated previously. In this study, we performed a combination of in vivo loss-of-function and in vitro gain-of-function studies to characterize the role of Runxl in neural progenitor cells. Our results strongly suggest that Runxl is important in these cells during the transition from proliferation to differentiation.

\section{Runx1 expression in the OE is correlated with ORN precursors undergoing differentiation}

The present investigations have shown that Runxl is not expressed in olfactory placodes or olfactory pits before E10.5, suggesting that Runx1 is not involved in early phases of olfactory neurogenesis. At E11.5, when primary neural progenitors are still actively relocating from apical to basal locations to give rise to secondary progenitors (Cau et al., 2002), Runx1 is expressed predominantly in dividing cells on the basal side of the OE. These findings suggest that Runx1 does not participate in mechanisms underlying the generation, proliferation, and/or survival of primary progenitor cells on the apical side. We have shown further that at least some of the dividing Runx1 + cells on the basal side of the OE express the Mash1 protein. Because Mash1 was shown to be expressed in a subset of basal ORN progenitors and to be required for the generation of these cells (Cau et al., 2002), our findings suggest that Runxl is expressed in defined populations of ORN progenitor cells. However, in contrast to Mash1, the expression of which is downregulated during the ORN progenitor-to-precursor transition (Cau et al., 2002), Runx1 expression persists in NeuroD+ ORN precursors, as well as in cells that display signs of early neuronal differentiation like the expression of $\beta$ III-tubulin (we recognize that the half-life of $\beta$-gal may be longer than that of Runxl and thus may persist in postmitotic cells longer than the latter). Together, these results suggest that Runx1 is expressed in certain populations of ORN progenitor and precursor cells during their proliferative phase and that its expression is downregulated concomitant with or shortly after terminal mitosis.

\section{Runx1 is important for the transition from proliferation to differentiation in both ORN and cortical progenitor-precursor cells}

Insight into the roles of Runxl in committed ORN progenitor cells has come from the analysis of embryos in which Runxl was inactivated. We have focused our studies on gestational day E11.5 for two reasons: (1) ORN differentiation is well under way by this stage and significant numbers of ORNs have already been generated, and (2) Runx1-mutant embryos die at $\sim$ E12.5 because of impaired fetal liver-derived hematopoiesis, thus precluding the study of later stages (North et al., 1999). Our findings have shown that Runxl inactivation is not correlated with a detectable loss of OE cells in which Runx1 would have been expressed at E11.5, but results instead in a redistribution of these cells from basal to more intermediate positions within the OE. To characterize this phenotype, we have examined the expression of Mash1, NeuroD, $\beta$ III-tubulin, and NCAM in the OE of Runx1-deficient and control embryos. Disruption of Runxl activity does not cause a decrease or an increase in the number of Mash $1+/ \beta$-gal+ cells, suggesting that Runxl is not important for the generation, pro- 


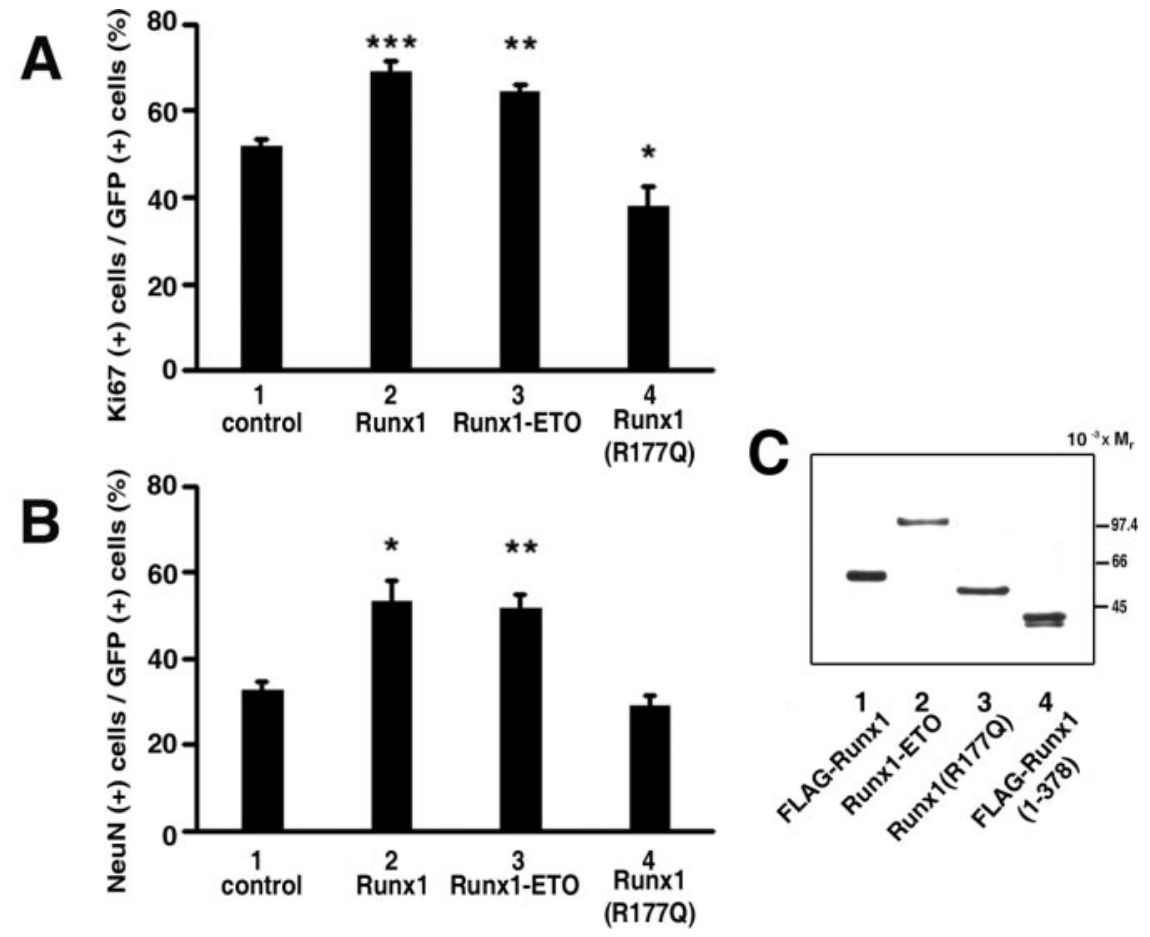

D

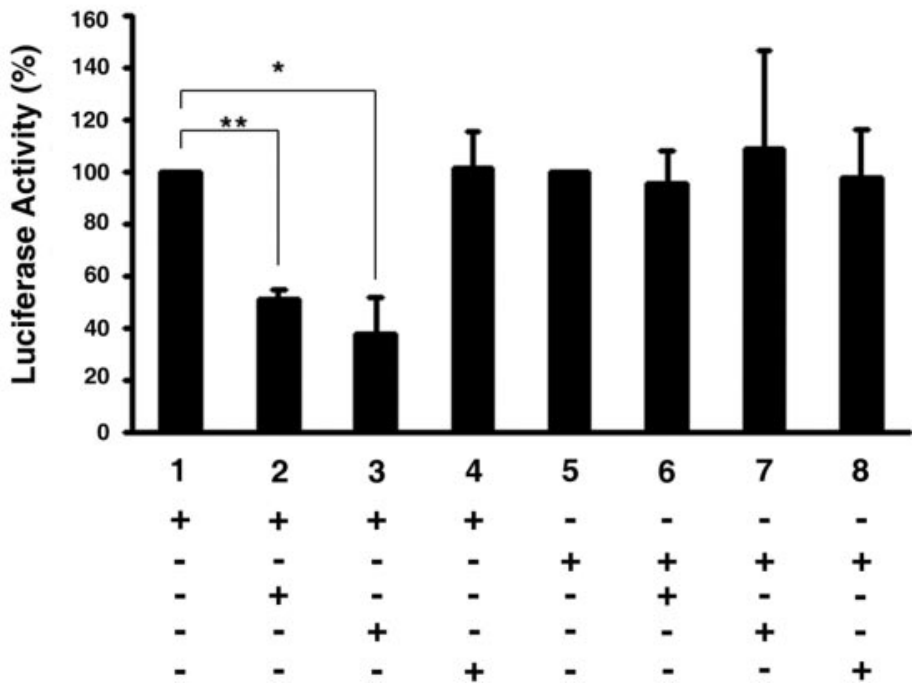

Figure 9. Exogenous expression of Runx1 or Runx1 mutants in cortical neural progenitor cells. $\boldsymbol{A}, \boldsymbol{B}$, Cortical progenitor cells were transfected with GFP alone (control, bar 1) or in combination with Runx1 (bar 2), Runx1-ET0 (bar 3), or Runx1(R1770) (bar 4), followed by double-labeling analysis and quantification as described in the legend to Figure 7 (mean $\pm S D ;>2000$ cells; $n=$ $4 ;{ }^{*} p<0.01 ;{ }^{* *} p<0.001 ;{ }^{* * *} p<0.0001$ ). C, Western blotting analysis of the indicated proteins using anti-Runx1 antibodies. $D$, Repression of transcription from the $p 21^{\text {Cip } 1}$ promoter by Runx1. Cortical neural progenitor cells were transfected with a plasmid encoding the luciferase gene under the control of the $p 21^{\text {Cip } 1}$ promoter in the absence (bar 1) or presence (bars 2-4) of the indicated proteins. A control pFOX-Luc1 promoter was also transfected alone (bar 5 ) or in the presence of the same proteins (bars 6 -8). The activity of each promoter in the absence of any expression plasmid was considered $100 \%$. Data are expressed as mean values \pm SD $\left(n=4 ;{ }^{*} p<0.01 ;{ }^{* *} p<0.001\right)$.

liferation, or survival of these progenitor cells. Instead, Runx1 inactivation is correlated with an $\sim 50 \%$ decrease in the number of NeuroD $+/ \beta$-gal + cells and a parallel increase in $\beta I I I-$ tubulin $+/ \beta$-gal + cells. This situation suggests that supernumerary NeuroD + precursors choose to differentiate into postmitotic ORNs in the absence of Runx1. In agreement with this possibility, we have observed a premature differentiation of ORNs in the dorsolateral region of the OE of E11.5 Runx1-deficient embryos. Together, these observations do not suggest that Runx1 is important for the survival of OE precursor cells because this situation would be expected to result not only in decreased numbers of NeuroD + cells but also differentiated neurons, contrary to the increase in the number of $\beta$ IIItubulin $+/ \beta$-gal + cells that we have observed. Instead, our findings suggest that Runxl is important for the sustained proliferation of ORN precursors and for coordinating the transition from proliferation to differentiation in the $\mathrm{OE}$.

A role for Runx 1 in the regulation of the precursor-to-neuron transition is also suggested by the results of our gain-offunction studies in primary cultures of olfactory and cortical progenitor cells. Exogenous Runx1 expression causes an increase in the number of undifferentiated cells undergoing proliferation, as determined through analysis of Ki67 and nestin expression, as well as BrdU incorporation studies; however, this effect is not correlated with a decrease but rather an increase in postmitotic neurons, as well as with an increase in the number of cells expressing both proliferation and differentiation markers, at least in cortical progenitor cultures. These findings suggest several possibilities. Exogenous Runx1 may promote a persistent activation of proliferation mechanisms, causing cells that have already entered the neuronal differentiation program to continue to undergo DNA synthesis and express markers typical of undifferentiated cells, like Ki67 and nestin. Alternatively, exogenous Runx1 may cause a premature activation of neuronal differentiation in proliferating progenitor-precursor cells (although this possibility appears less likely based on the finding that Runxl inactivation causes a premature neuronal differentiation, and not blocked-delayed differentiation, in the OE). It might also be possible that, at least in part, exogenous Runxl may alter the frequency of different progenitor subtypes leading to an increased representation of $\beta$ III-tubulin + proliferative cells. These observations strongly suggest that Runx1 participates in mechanisms that promote neural progenitor-precursor cell growth and coordinate proliferation and neuronal differentiation. Such a role would be similar to the demonstrated ability of the transcription factor Emx2 to both induce proliferation of cortical progenitors and promote their differentiation, thereby orchestrating the progenitor-to-neuron transition (Heins et al., 2001). This model is also consistent with a number of previous results. In the Drosophila embryonic nervous system, Runt is expressed in a restricted number of dividing neuroblasts after their commitment to the neuronal lineage but before terminal differentiation (Duffy et al., 1991; Dormand and Brand, 1998). Mammalian Runx1 promotes the proliferation of myeloid and lymphoid progenitor cells by accelerating the $G_{1}$ to $S$ phase progression, and a 
dominant-negative form of Runx1 causes cell-cycle arrest (Strom et al., 2000; Coffman, 2003; Bernardin-Fried et al., 2004); however, the proliferative effect of Runx1 does not inhibit the ability of myeloid progenitors to undergo differentiation (Lutterbach and Hiebert, 2000; Strom et al., 2000). Together, these observations strongly suggest that Runx1 plays an important role in coordinating the proliferation and neuronal differentiation of particular populations of neural progenitor cells.

\section{Transcription repression mechanisms underlie the function of Runx1 in cortical progenitor cells}

We have demonstrated that a DNA-binding defective form of Runxl does not promote an expansion of the progenitor cell pool in cortical progenitor cultures. Instead, it causes a small but statistically significant decrease in the number of progenitor cells, compared with control. These results strongly suggest that the proliferative effect of Runxl on these neural progenitors involves DNA-binding-dependent mechanisms. They also suggest that a DNA-binding-defective form of Runxl may have a dominantnegative effect on the functions performed by endogenous Runx1, likely by sequestering its transcriptional cofactors away from DNA.

When bound to DNA, Runxl can mediate transcriptional activation or repression, depending on the particular promoter context. To elucidate the mechanisms underlying Runx1 activity in neural cells, we have used Runx1/ETO, the naturally occurring fusion protein containing the DNA-binding domain of Runx1 fused to the transcriptional repressor ETO. Runx1/ETO retains the ability to bind to consensus Runx DNA-binding sites, where it mediates transcriptional repression (Linggi et al., 2002). This enables it either to interfere with the transactivating functions of Runx1 in a dominant-negative manner or mimic Runx1mediated transcriptional repression. We found that exogenous Runx1/ETO phenocopies the effect of exogenous Runx1, strongly suggesting that transcription repression mechanisms are involved in at least some of the events underlying Runxl function in cortical neural progenitor cells. This possibility is also suggested by our direct demonstration that Runxl can mediate transcriptional repression in these cells and inhibit transcription from the promoter of the $p 21^{\text {Cip } 1}$ cell-cycle inhibitory gene. This finding raises the additional possibility that the negative regulation of the expression of $p 21^{\text {Cip } 1}$ and/or other related genes like $p 27^{\text {Kip } 1}$ may represent at least one mechanism used by Runx1 to promote neural progenitor cell proliferation. In the future, it will be important to determine whether Runxl also mediates transcriptional repression in ORN progenitor cells and whether its transcription repression functions are important for the regulation of ORN differentiation.

\section{References}

Bernardin-Fried F, Kummalue T, Leijen S, Collector MI, Ravid K, Friedman AD (2004) AML1/RUNX1 increases during G1 to $S$ cell cycle progression independent of cytokine-dependent phosphorylation and induces cyclin D3 gene expression. J Biol Chem 279:15678-15687.

Bertrand N, Castro DS, Guillemot F (2002) Proneural genes and the specification of neural cell types. Nat Rev Neurosci 3:517-530.

Caggiano M, Kauer JS, Hunter DD (1994) Globose basal cells are neuronal progenitors in the olfactory epithelium: a lineage analysis using a replication-incompetent retrovirus. Neuron 13:339-352.

Calof AL, Bonnin A, Crocker C, Kawauchi S, Murray RC, Shou J, Wu HH (2002) Progenitor cells of the olfactory receptor neuron lineage. Microsc Res Tech 58:176-188.

Carter LA, MacDonald JL, Roskams AJ (2004) Olfactory horizontal basal cells demonstrate a conserved multipotent progenitor phenotype. J Neurosci 24:5670-5683.
Cau E, Gradwohl G, Fode C, Guillemot F (1997) Mash1 activates a cascade of bHLH regulators in olfactory neuron progenitors. Development 124:1611-1621.

Cau E, Casarosa S, Guillemot F (2002) Mash1 and Ngn1 control distinct steps of determination and differentiation in the olfactory sensory neuron lineage. Development 129:1871-1880.

Coffman JA (2003) Runx transcription factors and the developmental balance between cell proliferation and differentiation. Cell Biol Int 27:315-324.

Davis RL, Turner DL (2001) Vertebrate hairy and enhancer of split related proteins: transcriptional repressors regulating cellular differentiation and embryonic patterning. Oncogene 20:8342-8357.

Dormand EL, Brand AH (1998) Runt determines cell fate in the Drosophila embryonic CNS. Development 125:1659-1667.

Duffy JB, Kania MA, Gergen JP (1991) Expression and function of the Drosophila gene runt in early stages of neural development. Development 113:1223-1230.

Galli LM, Willert K, Nusse R, Yablonka-Reuveni Z, Nohno T, Denetclaw W, Burrus LW (2004) A proliferative role for Wnt-3a in chick somites. Dev Biol 269:489-504.

Ghosh A, Greenberg ME (1995) Distinct roles for bFGF and NT-3 in the regulation of cortical neurogenesis. Neuron 15:89-103.

Gratton MO, Torban E, Belanger-Jasmin S, Theriault F, German MS, Stifani S (2003) Hes6 promotes cortical neurogenesis and inhibits Hes1 transcription repression activity by multiple mechanisms. Mol Cell Biol 23:6922-6935.

He TC, S. Zhou, da Costa LT, Yu J, Kinzler KW, Vogelstein B (1998) A simplified system for generating recombinant adenoviruses. Proc Natl Acad Sci USA 95:2509-2514.

Heins N, Cremisi F, Malatesta P, Gangemi RMR, Corte G, Price J, Goudreau G, Gruss P, Gotz M (2001) Emx2 promotes symmetric cell divisions and a multipotential fate in precursors from the cerebral cortex. Mol Cell Neurosci 18:485-502.

Inoue K, Ozaki S, Shiga T, Ito K, Masuda T, Okado N, Iseda T, Kawaguchi S, Ogawa M, Bae SC, Yamashita N, Itohara S, Kudo N, Ito Y (2002) Runx3 controls the axonal projection of proprioceptive dorsal root ganglion neurons. Nat Neurosci 5:946-954.

Kanno T, Kanno Y, Chen LF, Ogawa E, Kim WY, Ito Y (1998) Intrinsic transcriptional activation-inhibition domains of the polyomavirus enhancer binding protein $2 /$ core binding factor $\alpha$ subunit revealed in the presence of the $\beta$ subunit. Mol Cell Biol 18:2444-2454.

Levanon D, Bettoun D, Harris-Cerruti C, Woolf E, Negreanu V, Eilam R, Bernstein Y, Goldenberg D, Yiao C, Fliegauf M, Kremer E, Otto F, Brenner O, Lev-Tov A, Groner Y (2002) The Runx3 transcription factor regulates development and survival of TrkC dorsal root ganglia neurons. EMBO J 13:3454-3463.

Linggi B, Muller-Tidow C, van de Locht L, Hu M, Nip J, Serve H, Berdel WE, van der Reijeden B, Quelle DE, Rowley JD, Cleveland J, Jansen JH, Pandolfi PP, Hiebert SW (2002) The $\mathrm{t}(8: 21)$ fusion protein, AML1ETO, specifically represses the transcription of the p14(ARF) tumor suppressor in acute myeloid leukemia. Nat Med 8:743-750.

Lund AH, van Lohuizen M (2002) RUNX: a trilogy of cancer genes. Cancer Cell 1:213-215.

Lutterbach B, Hiebert SW (2000) Role of the transcription factor AML-1 in acute leukemia and hematopoietic differentiation. Gene 245:223-235.

Lutterbach B, Westendorf JJ, Linggi B, Seto E, Hiebert SW (1999) A mechanism of transcriptional repression by AML-1, the target of multiple chromosomal translocations in acute leukemia. J Biol Chem 275:651-656.

McLarren KW, Lo R, Grbavec D, Thirunavukkarasu K, Karsenty G, Stifani S (2000) The mammalian basic helix loop helix protein HES-1 binds to and modulates the transactivating function of the Runt-related factor Cbfa1. J Biol Chem 275:530-538.

Mumm JS, Shou J, Calof AL (1996) Colony-forming progenitors from mouse olfactory epithelium: evidence for feedback regulation of neuron production. Proc Natl Acad Sci USA 93:11167-11172.

North T, Gu TL, Stacy T, Wang Q, Howard L, Binder M, Marin-Padilla M, Speck N (1999) Cbfa2 is required for the formation of intra-aortic hematopoietic clusters. Development 126:2563-2575.

Nuthall HN, Joachim K, Stifani S (2004) Phosphorylation of serine 239 of Groucho/TLE1 by protein kinase CK2 is important for inhibition of neuronal differentiation. Mol Cell Biol 24:8395-8407. 
Osato M, Asou N, Abdalla E, Hoshino K, Yamasaki H, Okubo T, Suzushima H, Takatsuki K, Kanno T, Shigesada K, Ito Y (1999) Bialleleic and heterozygous point mutations in the Runt domain of the AML1/PEBP2 $\alpha \mathrm{B}$ gene associated with myeloblastic leukemias. Blood 93:1817-1824.

Othman MM, Klueber KM, Roisen FJ (2003) Identification and culture of olfactory neural progenitors from GFP mice. Biotech Histochem 78:57-70.

Roskams AJ, Cai X, Ronnett GV (1998) Expression of neuron-specific betaIII tubulin during olfactory neurogenesis in the embryonic and adult rat. Neuroscience 83:191-200.

Sherr CJ (2004) Principles of tumor suppression. Cell 116:235-246.

Simeone A, Daga A, Calabi F (1995) Expression of runt in the mouse embryo. Dev Dyn 203:61-70.

Smart IH (1971) Location and orientation of mitotic figures in the developing mouse olfactory epithelium. J Anat 109:243-251.

Speck NA, Gilliland DG (2002) Core-binding factors in hematopoiesis and leukemia. Nat Rev Cancer 2:502-513.

Strom DK, Nip J, Westendorf JJ, Linggi B, Lutterbach B, Downing JR, Lenny
N, Hiebert SW (2000) Expression of the AML-1 oncogene shortens the G1 phase of the cell cycle. J Biol Chem 275:3438-3445.

Theriault FM, Roy P, Stifani S (2004) AML1/Runxl is important for the development of hindbrain cholinergic branchiovisceral motor neurons and selected cranial sensory neurons. Proc Natl Acad Sci USA 101:10343-10348.

Toma JG, El-Bizri H, Barnabe-Heider F, Aloyz R, Miller FD (2000) Evidence that helix-loop-helix proteins collaborate with retinobloastoma tumor suppressor protein to regulate cortical neurogenesis. J Neurosci 20:7648-7656.

Wang Q, Stacy T, Binder M, Marin-Padilla M, Sharpe AH, Speck NA (1996) Disruption of the $C b f a 2$ gene causes necrosis and hemorrhaging in the central nervous system and blocks definitive hematopoiesis. Proc Natl Acad Sci USA 93:3444-3449.

Yao J, Lai E, Stifani S (2001) The winged-helix protein brain factor-1 interacts with Groucho and Hes proteins to repress transcription. Mol Cell Biol 21:1962-1972.

Zhang X, Kueber KM, Guo Z, Lu C, Roisen FJ (2004) Adult human olfactory neural progenitors cultured in defined medium. Exp Neurol 186:112-123. 